\title{
China: An Expatriate's Discovery Of Culture And Customs
}

\author{
V. Joy Rose, Saint Leo University, USA
}

\begin{abstract}
The purpose of this research paper is to share and uncover the differences between American and Chinese culture and customs. These revelations illustrate the culture and customs of various Chinese provinces and how they differ from those of the United States. Moreover, an analysis of etiquettes, business practices, the concept of face, and teaching experiences are provided. In conclusion, this paper will touch upon the experiences of an expatriate while teaching at a renowned Chinese university. The viewpoints are based on experiences and observations only and, in no way, reflect the nature and culture of China as a whole. The findings of this paper will also help Americans, either traveling or teaching overseas, to prepare themselves, and will enable the reader to form his or her own perception and draw conclusions from an individual perspective.
\end{abstract}

Keywords: China; Teaching; Culture; Customs; Etiquette; Travel

\section{INTRODUCTION}

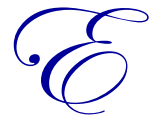

tiquette is determined by and evolves within culture. It varies between different cultures and nations, and one must understand this variation in terms of the impact etiquette has on global business success. According to Okoro (2012), "Increasingly, corporations recognize the value of preparing global managers, because business objectives of are not achieved primarily because of deficiencies in cross-cultural etiquette." Customs that are traditional and non-traditional vary among cultures. Although there are countless cultural differences, this paper will focus on the three main subtopics of etiquette, education, and social responsibility. This is accomplished through the observations of an expatriate professor on a five-month teaching term in China. There is no question that China will continue to be a major player in the world economy. China's population is over 1.3 billion, with most provinces bordering the ocean. In 2010, observations were gathered from Shanghai, Zhuhai, Hong Kong, Macau, Shenzhen, and Guangzhou provinces. We will first explore the definitions of culture, which, according to Cardemil, is a complex notion: "Culture is a very difficult concept to accurately define and operationalize.... many within-group differences exist that create heterogeneity in cultural groups, thus complicating the effort to develop an adaptation for a particular cultural group" (Cardemil, 2010).

Over the past century, many definitions of culture have been formalized. One work, published in 1952, indicated that as many as 169 definitions of culture exist in all languages across the globe. One of the definitions is as follows: "that complex whole, which includes knowledge, belief, art, morals, law, custom, and any other capabilities acquired by man as a member of society" (Ferraro \& Andreatta, 2009, p. 28). Another definition asserts that culture is "a mental map which guides us in our relations to our surroundings and to other people" (Downs, 1971). Yet another definition states that "culture is everything people have, think, and do as members of a society" (Ferraro \& Andreatta, 2009, p. 28). No matter what the definition, the underlying concept is that culture is a pattern regarding what people in a society consider as acceptable.

\section{BUSINESS ETIQUETTE}

In the business sector, there are certain similarities as well as differences between Chinese and American customs. Developing trust before engaging in a business transaction is typical to both the Chinese and Americans. For instance, one way to develop this trust that I observed is to be punctual for all meetings. Although my meetings 
were in Chinese, I had an interpreter. I sat quietly until asked to speak. In China, silence is a good business practice, enabling one to collect his or her thoughts. Negotiating business deals in China is a delicate process that requires patience and endurance while dealing with all levels of employees. Chinese respect their seniors and, sometimes, maintaining silence while a senior talks is taken as a sign of respect (Moore \& Woodrow, 2010). During our meetings, I observed that while a person was speaking, no one interrupted or interjected comments until the speaker concluded the point. I found this to be interesting since this was not the case in many non-Chinese meetings I had attended.

In China, I was unaware that meetings were planned with short notice and that failure to attend was frowned upon. I remember being told to attend a meeting just as I was getting ready to retire for the evening. Another similarity between Chinese and American cultures is the initial business greeting, which includes an exchange of business cards. The front of a business card should include information in English while the back should include information in the language of the country one is traveling to during foreign trips. Before I left for China, I had my business cards printed in Mandarin on the back. This was a very insightful move because I was looked upon as a person of trust who wanted to learn the Chinese customs. I also observed that in China, business cards were accepted with both hands and a nod while Americans receive a card with only one hand and it is put away to be read later. I was told that in China, it was disrespectful to take a business card and not read it; additionally, anyone using the information for any other purpose than what was intended for was frowned upon.

\section{Greetings}

When greetings are exchanged in Zhuhai, China, the oldest person is formally greeted first with a nod or bow. According to Yue and Ng (1999), "Old people continue to hold high filial expectations for young people and young people still endorse strongly filial obligations for old people." Unlike American culture, greetings are exchanged with a handshake, regardless of the person's age. The handshake is also used as a symbol of sealing a business deal (DeMente, 2008). As an American, I obviously extended my hand to many Chinese, but it was refused sometimes because it was not the norm. However, there was a great willingness to learn American culture as well.

American culture generally teaches citizens to engage in eye contact, but while greeting some Chinese citizens, I did not find eye contact to be very common. They tend to look down during greetings. I experienced a situation in which some Chinese citizens did not smile or exchange greetings with me since I was considered a stranger. According to my Chinese students, smiling or being friendly to someone you don't know well is sometimes considered rude and intrusive. The Chinese prioritize respect and don't make eye contact as readily as Americans do. As a part of a collectivist society, they are very concerned about the impressions they make and their relationships with others, as compared to Americans, who are individualistic and do not tend to be intimidated by authorities (Moore \& Woodrow, 2010). While exchanging greetings, both American and Chinese citizens use titles and surnames as a courtesy until a person is invited to address a person on a first-name basis (Fanco, 2004). However, titles are of the utmost importance to Chinese business professionals. To them, it is important to use what we Americans call Mr., Mrs., or Miss, as these show respect (Kenna \& Lacy, 1994).

\section{Tipping}

In Chinese culture, older workers view tipping as an insult. However, tipping is more popular among youngsters owing to the widespread influence of new media such as YouTube, Twitter, and a host of other sites that popularize American culture. "Tipping is a long-standing custom in North America, but it is new in China, and it is perceived as an extra cost rather than as a gesture to show appreciation to the servers" (Bian \& Keller, 1999, p. 312). Although tipping is frowned upon in China, there are some places that accept tips with no fixed amount as it is in American culture. In America, if service is good, a tip of $15 \%-20 \%$ is given. However, if service is unsatisfactory, a complaint is registered or a smaller (or no) tip is left. "Most notably, business students in both China and the United States tip less in a restaurant that they would not visit again than in a restaurant they visit frequently" (Bian \& Keller, 1999, p. 213). 


\section{TEACHING EXPERIENCE}

\section{Accepting a Visitor}

Teaching in China was the best decision I ever made. In China, I was treated as a diplomat. I was saluted every day by the guards that surrounded the campus. Students wanted to carry my books and bags; they offered to take me shopping and keep me company as a new American on campus. Once acclimated to the campus, I was stared at, touched, and treated with the utmost respect. I was the first African American to visit this campus, and many of the students had never seen a person of the African American background before. I observed a great enthusiasm for learning among the students there. Chinese students wake early in the morning. With unfailing discipline, they strive to become ideal future leaders of China.

When I first arrived, it was dark, and I was given a key and sent to my apartment. I was expecting a tour first, but it was a custom for a newcomer to find his or her own way. I did not have a car, and the only transportation available was a mini bus, which came every hour, or a bike. I opted to walk to campus every day for five months.

\section{Face}

Americans are generally considered confrontational while Chinese often do not speak up if they believe that something is wrong. From their perspective, "silence is golden," and often they will not mention problems for fear of jeopardizing a relationship. This concept is called "Face". "Face is a more inclusive concept than honor and dignity. Honor may be viewed as a special kind of face that is claimed by certain elitist groups in a society" (Ho, 1976). The Chinese often avoid embarrassment at any cost. To them, it is more important to be honest, "face facts", make their views known, and put across their questions and disagreements. I observed a student being reprimanded by his teacher; while this occurred, he stood looking down on the floor and said nothing. I was surprised to see this because in America, a student would either leave the room or lash back at the teacher. It is noted that the "Chinese consider it rude to say 'no' directly to a person. They often respond 'maybe,' 'I am busy,' or even 'yes' when they really mean 'no,' or convey a 'no' answer in ways that foreigners don't understand" (Moore \& Woodrow, 2010). This was extremely baffling to me, which caused me to dig for a more concise answer, but all I got was, "maybe".

\section{Classroom Practices}

My classes started at 8:00 a.m. every day. On my arrival, I would hear something like chants streaming down the halls. Once I arrived in class, I would see 30 Chinese students reading aloud. On many occasions, I heard them practicing their assignments as they sat ready for the day's lesson. Students were seldom late for class, and if they were, they would experience the shame of chatter from the students as they took their seats. Chinese students do not raise their hands like American students are taught to do. This can be attributed to their culturally ingrained methods of responding to adults and seniors (Singh, Huang, \& Thompson, 1962). I once asked students to answer a question while lecturing and did not see any hands, so I moved on. A student asked me after class why I did not select anyone. I told her that I did not see anyone who wanted to answer. It was then that she stated that Chinese students only raise their hands midway and not extended high in the air.

\section{Education System}

The Chinese believe that education gives a student an upper hand in life and provides numerous opportunities. They encourage all to study hard to enhance their knowledge because they want to position themselves prominently in the global economy. This is how the Chinese have been classified as an emerging economy because they tend to be very competitive (Kenna \& Lacy, 1994). The academic atmosphere for this university is somewhat strict as compared to that of American colleges. Chinese students who attend college at Zhuhai College of Jilin University have a schedule from 8:00 a.m. to 6:00 p.m. every day. They have a curfew of 11:00 p.m. every night. The campus is locked up at midnight and all phones and computers have to be shut down. Students are not allowed to leave the campus unless escorted by a family member or a teacher. The entire campus is surrounded by mountains, and a security guard is stationed at every entrance. Visiting lecturers may leave whenever they wish, but it is advisable to have someone with them who understands and speaks Chinese. 


\section{CONCLUSION}

Lack of awareness of the different types of nonverbal communication in different cultures could greatly affect the outcome in a business setting. When putting oneself at the negotiating table, be it for business or any other political matter, it is best to know the culture of the other party to find common ground on which to establish communication. Knowing the other party's culture is important for understanding the communication process and is a key factor in being able to bridge cultural chasms.

\section{AUTHOR INFORMATION}

V. Joy Rose, Ph.D., is an Assistant Professor of Management in the Donald R. Tapia School of Business at Saint Leo University, 1303 Highland Bluff DR SE, Atlanta, GA 30339 USA. She earned her doctorate at Capella University. Dr. Rose published in the Journal of Applied Management and Entrepreneurships. She has also presented her work, "Strategic Alliances for a Global Economy - The Impact of International Business in the Southeastern United States" at Zhuhai College of Jilin University. Her research interests include international business, teaching, and flood insurance management. E-mail: vase.rose@ saintleo.edu

\section{REFERENCES}

1. Bian, W. Q., \& Keller, L. R. (1999). Patterns of fairness judgments in North America and the People's Republic of China. Journal of Consumer Psychology, 8(3), 301-320.

2. Cardemil, E. V. (2010). The Complexity of Culture: Do We Embrace the Challenge or Avoid It? Scientific Review Of Mental Health Practice, 7(2), 41-47.

3. DeMente, B. (2008). Etiquette guide to China: Know the rules that make the difference. Tuttle Publishing.

4. $\quad$ Downs, J. F. (1971). Culture in Crisis, Glencoe Press, Beverly Hills, Calif.

5. Fanco, A. (2004). The table manner coach. AMG Direct LLC.

6. Ferraro, G. P., \& Andreatta, S. (2009). Cultural Anthropology: An Applied Perspective. New York: Cengage Learning.

7. Ho, D. Y. (1976). On the concept of face. American Journal of Sociology, 867-884.

8. Kenna, P., \& Lacy, S. (1994). Business China: A practical guide to understanding Chinese business culture. Passport Books.

9. Moore, C., \& Woodrow, P. (2010). Handbook of Global and Multicultural Negotiations. San Francisco: Jossey-Bass.

10. Okoro, E. (2012). Cross-Cultural Etiquette and Communication in Global Business: Toward a Strategic Framework for Managing Corporate Expansion. International Journal Of Business \& Management, 7(16), 130-138.

11. Overmyer, D. (May 1995). The Journal of Asian Studies, Vol. 54, 314-321. Retrieved from http://www.sino.uni-heidelberg.de/staff/janku/hilfsmittel/religion/jas1.pdf

12. Sereny, M. (2011). Filial Piety, Family Values, and Exchanges between Generations. Retrieved from http://paa2011.princeton.edu/papers/110782, http://paa2011.princeton.edu/papers/110782

13. Singh, P. N., Huang, S. C., \& Thompson, G. G. (1962). A comparative study of selected attitudes, values, and personality characteristics of American, Chinese, and Indian students. The Journal of Social Psychology, 57(1), 123-132.

14. Yue, X., \& Ng, S. (1999). Filial Obligations and Expectations in China: Current Views from Young and Old People in Beijing. Asian Journal Of Social Psychology, 2(2). 